\title{
DIGITAL ENTREPRENEURSHIP IN THE LAST DECADE: A SYSTEMATIC REVIEW
}

\author{
Amadi Chimezie Paulinus \\ Department of Entrepreneurship and Business Studies \\ Federal University of Technology Minna, Nigeria \\ chimezieamada@gmail.com \\ Umaru Mustapha Zubairu \\ Department of Entrepreneurship and Business Studies \\ Federal University of Technology Minna, Nigeria \\ uzubairu@gmail.com \\ Olalekan Busra Sakariyan \\ Department of Entrepreneurship and Business Studies \\ Federal University of Technology Minna, Nigeria \\ kanzak@,futminna.edu.ng

\section{Isah Imam Paiko} \\ Department of Entrepreneurship and Business Studies \\ Federal University of Technology Minna, Nigeria \\ paikolupa@yahoo.com
}

\begin{abstract}
This paper investigates the effects Information Communications Technology has on the sustainability of Digital Entrepreneurship in Nigeria. Furthermore, this paper seeks to uncover if the utilization of ICT can forecast the rate of new enterprises in the Digital Entrepreneurship sector and interrogate the attributes and interconnections inherent in Digital Entrepreneurship. Literature review using the Systematic Quantitative Assessment Technique (SQAT) was the methodology used to review $45 \mathrm{DE}$ articles published in the last ten years $(2012-2021)$. For a thorough, impartial amalgam of the reviewed articles, this paper analysed the types, period, location, and data collection methods of the 45 Digital Entrepreneurship papers. The review showed that existing research has been both empirical and conceptual in equal measure with only one instance in mixed mode. The parity suggests that future researchers should endeavour to conduct more conceptual research to underpin the envisaged accelerated growth of DE.
\end{abstract}

Keywords: Digital Entrepreneurship, Digitalisation, Systematic Assessment Technique, Technology

Received: 28 April 2021 ;

Accepted: 16 August 2021 ;

Publish: December 2021

How to Cite:

Paulinus, A.C., et.al. (2021). Digital Entrepreneurship in The Last Decade: A Systematic Review. Journal of Business and Behavioural Entrepreneurship, 5(2), 64-78. https://doi.org/10.21009/JOBBE.005.2.09 


\section{INTRODUCTION}

Digital Entrepreneurship features "changes in entrepreneurial practice, theory and education therefore, it is of high topicality as technological developments and advances in infrastructure create various opportunities for entrepreneurs" (Zanheer et al., 2019). This opens up new possibilities for anyone considering becoming an entrepreneur; albeit some opportunities are more technical, but numerous others are within reach for anyone who learns the fundamental competences of Digital Entrepreneurship. These fundamental skills include finding new customers online, prototyping new business ideas and improving business ideas based on data. The Digital Entrepreneurship fosters growth and productivity and also supports inclusive development (Askerov et al., 2019; Yin et al., 2019).

Entrepreneurship is the activity of setting up a business or organisation, taking on financial risks in the expectation of value creation and profit making. Furthermore, "entrepreneurship will change as business and society continue to be transformed by advanced innovation via digital technology" (Richter et al., 2017). "The rapid developments in information and communication technologies and their increased utilization motivate the vision of an evolving digital economy" (Quinton et al., 2018). The quick diffusion of ICTs has produced significant "changes in how goods and services are produced, the nature of the goods and services produced, and the means by which goods and services are brought to the market and distributed to customers" (Quinton et al., 2018). During the last decade, this evolving Digital Entrepreneurship has been the "preeminent driver of structural change and economic growth at both the national and the regional levels in the developed and developing economies" (Barefoot et al., 2018).

However, "there are substantial differences among countries and regions as regards their role in the development of Digital Entrepreneurship and their propensity to adopt and apply ICT applications in various sectors and activities. Hence, countries and regions differ markedly in how far they have come on the road to the Digital Entrepreneurship" (Zaheeer et al., 2019).

Founders of new ventures seem to focus on their immediate stakeholders, including customers, employees, suppliers and investors but not on the broader impact of ICT on the long-term sustainability of their enterprise. Capital, Product or Service and Marketing are "the three key pillars through which a startup can become a sustainable enterprise in the long run" (Hamid \& Khalid, 2016). Many new enterprises end up focusing on one or two of these pillars, which negatively affects them. For instance, many companies tend to focus only on raising funds and marketing, while ignoring product or service development via the use of ICT (Johansson et al., 2006).

The properties of Digital Entrepreneurship and information communications technology and how they interrelate is complicated. In this digital age, it is essential to understand this interrelationship which is a central plank for innovation that underpins economic growth.

There are several issues regarding Digital Entrepreneurship and ICT inhibiting digital entrepreneurs from optimising the advantages that Digital Entrepreneurship adds to business. This paper examines these issues and their impact on businesses.

Furthermore, this study also seeks to determine whether the utilization of ICT can conjecture the rate of start-ups in the Digital Entrepreneurship sector. 


\section{RESEARCH METHODS}

In conducting a methodical review of scholarship on Digital Entrepreneurship (DE) in the last decade, the methodology adopted by this study is the Systematic Quantitative Assessment Technique (SQAT). Australian researchers, Pickering and Byrne developed SQAT in 2014. The method "allows researchers to systematically analyse existing academic literature to produce a structured quantitative summary of the subject to determine their inclusion or exclusion in the review process and focuses on peer-reviewed original journal publications so as to maintain a high quality of articles" (Pickering and Byrne, 2014). SQAT "enables the researcher to identify important geographic, scalar, theoretical and methodological gaps in the literature" (Pickering and Byrne, 2014). SQAT also lends itself to being straightforward, logical and simple to use which are all essential elements of a systematic review.

SQAT endorses five significant rungs in achieving a sound methodical review as described in Table 1.

Table 1: The Five Steps of SQAT

\begin{tabular}{|c|c|c|}
\hline $\mathbf{S} / \mathbf{N}$ & Step & Application in Current Study \\
\hline 1. & Outline the topic & $\begin{array}{l}\text { Digital Entrepreneurship (DE) articles published be- } \\
\text { tween } 2012 \text { and } 2021\end{array}$ \\
\hline 2. & $\begin{array}{l}\text { Articulate the research } \\
\text { questions }\end{array}$ & $\begin{array}{l}\text { Five research questions: } \\
\text { When were the DE articles published? } \\
\text { Where were the DE articles written? } \\
\text { Were the published DE articles Conceptual vs. Em- } \\
\text { pirical? } \\
\text { What method was used to collect data? } \\
\text { What themes did these DE articles explore, and what } \\
\text { were the major findings? }\end{array}$ \\
\hline 3. & Name the key words & "Digital Entrepreneurship" \\
\hline 4. & Search and Find databases & $\begin{array}{l}\text { Six databases utilized: Emerald, Elsevier, Sage, } \\
\text { Springer, Wiley and Taylors \& Francis } \\
\text { "All in title search" with the phrase "Digital Entre- } \\
\text { preneurship" }\end{array}$ \\
\hline 5 . & Scrutinize publications & $\begin{array}{l}\text { The found publications were perused to ensure they } \\
\text { were dealing only with Digital Entrepreneur- } \\
\text { ship. } \\
\text { Only peer-reviewed conceptual and empirical DE } \\
\text { articles were included. }\end{array}$ \\
\hline
\end{tabular}

Source: Author's review (2021)

A total of 45 published DE articles from six prominent academic journal publishers were chosen. Table 2 presents the DE article breakdown by publisher. 
Table 2: DE articles reviewed by publisher (2012-2021)

\begin{tabular}{|c|l|c|}
\hline S/N & Publisher & Number of DE articles \\
\hline 1. & Elsevier & 16 \\
\hline 2. & Springer & 11 \\
\hline 3. & Sage & 9 \\
\hline 4. & Emerald & 5 \\
\hline 5. & Wiley & 4 \\
\hline 6. & Taylors \& Francis & 0 \\
\hline & Total & $\mathbf{4 5}$ \\
\hline
\end{tabular}

Source: Author's review (2021

\section{RESULTS AND DISCUSSIONS}

\section{Time of the Publication of DE articles}

Figure 1 outlines the time of the publication of the $45 \mathrm{DE}$ articles examined for this study over the last decade, 2012-2021.

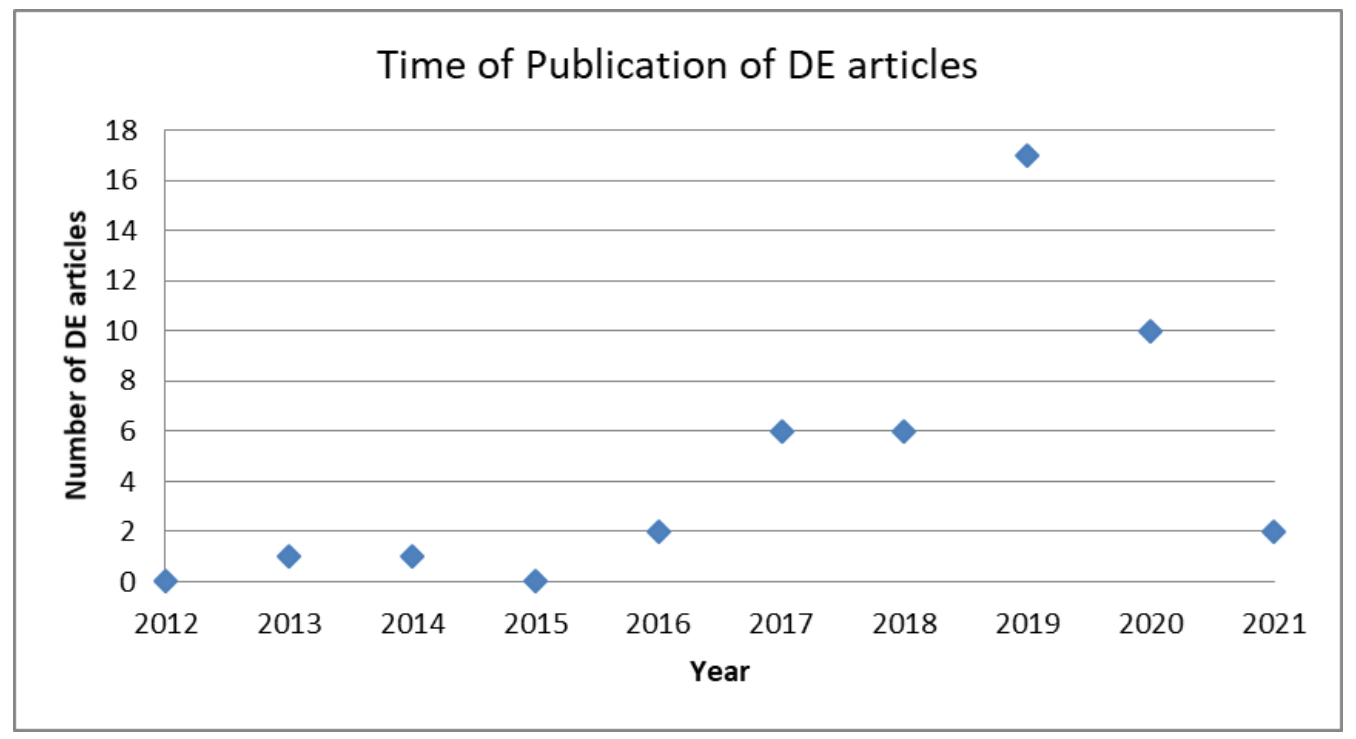

Figure 1: Time distribution of DE articles

Source: Author's review (2021)

The study revealed that Digital Entrepreneurship articles made their debut in academic journals in 2013 with just one instance and a similar number in 2014. By 2015 it seemed that interest in the subject had waned as there was no publication on the topic that year. Interest rose again in 2016 with two publications and surged to six instances in both 2017 and 2018. The numbers spiked to 17 in 2019, but took a dip to 10 in 2020 and tapered off to just two in 2021. It can be observed that DE articles were 
published successively from 2013 to 2021 except in 2015.

\section{Geographic distribution of DE articles}

A review of the $45 \mathrm{DE}$ journal articles revealed that 23 countries were represented, and Figure 2 presents the top four countries from which these articles originated from over the last decade, 2012-2021.

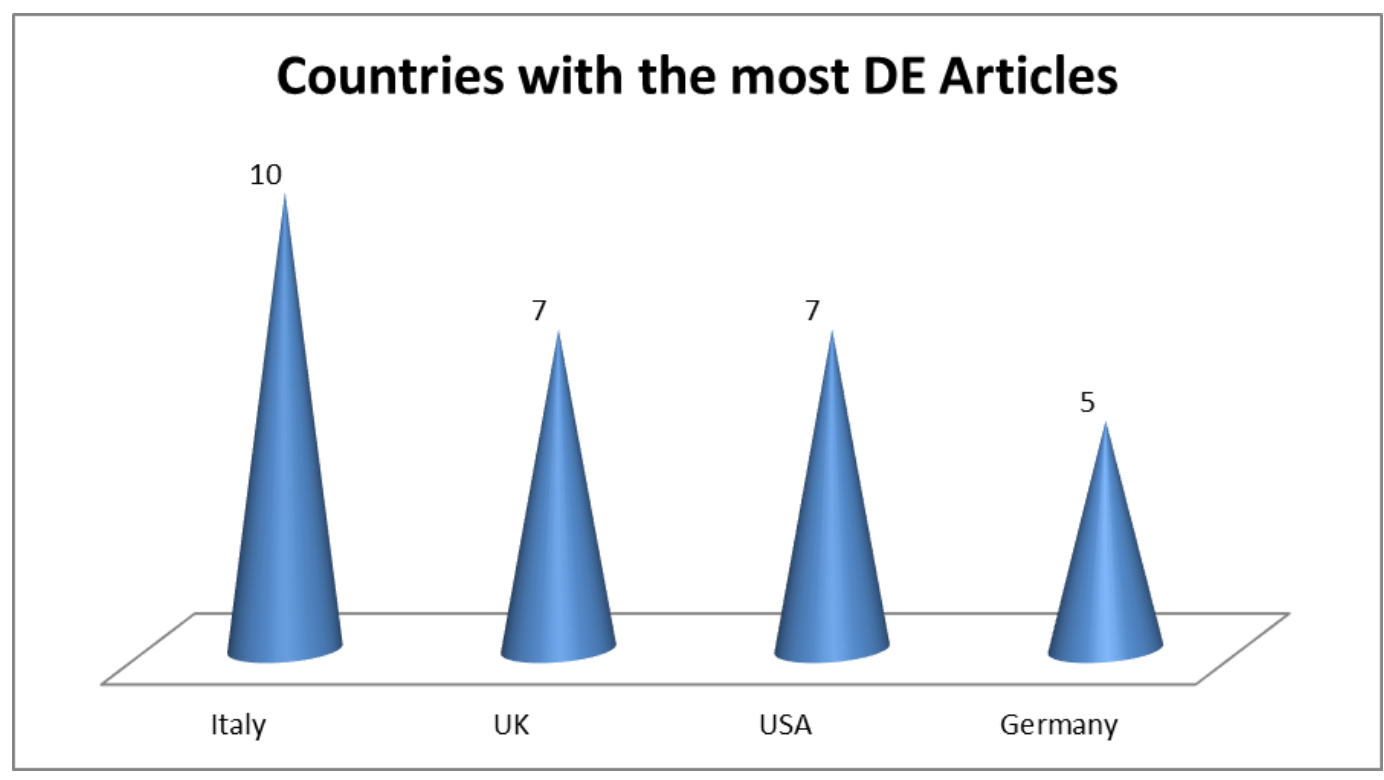

Figure 2: Time distribution of DE articles

Source: Author's review (2021)

Italy had by far the most number of DE articles with 10 , followed by the UK and USA with 7 articles respectively, and then Germany with five.

The remaining 19 countries and the number of DE articles associated with them are presented in Table 3.

In order to provide an additional perspective of the geographic distribution of DE articles published in the last decade, Figure 3 provides a breakdown of the 45 articles based on the continent they originated from. Europe had the largest number of published DE articles (42), North America (8), Asia (7), and then Africa (3). On the other hand, Australasia and South America only had one DE article apiece. 
Table 3: 19 remaining countries and the DE articles associated with them

\begin{tabular}{|l|l|c|}
\hline S/N & \multicolumn{1}{|c|}{ Country } & Number of Articles \\
\hline 1 & France & 4 \\
\hline 2 & Ireland & 3 \\
\hline 3 & China & 3 \\
\hline 4 & Spain & 3 \\
\hline 5 & Netherlands & 3 \\
\hline 6 & Liechtenstein & 2 \\
\hline 7 & Sweden & 2 \\
\hline 8 & South Korea & 2 \\
\hline 9 & Australia & 1 \\
\hline 10 & Brazil & 1 \\
\hline 11 & Canada & 1 \\
\hline 12 & Denmark & 1 \\
\hline 13 & Finland & 1 \\
\hline 14 & India & 1 \\
\hline 15 & Morocco & 1 \\
\hline 16 & Nigeria & 1 \\
\hline 17 & Sudan & 1 \\
\hline 18 & Taiwan & 1 \\
\hline 19 & Turkey & 1 \\
\hline & & \\
\hline
\end{tabular}

Source: Author's review (2021)

Digital Entrepreneurship is the smart application of the powerful "digital technologies to business; it is about creating added value for your customers using information and communication technology with the aim of making business gains and includes redefining the value chain, disrupting existing value propositions and creating new ones leveraging the power of digital technologies." (G. Nedumaran et al., 2020).

From geographic gap analysis, African, Australasian and South American countries are perhaps most in need of Digital Entrepreneurship, as these countries trail their counterparts in the global north and Asia. The 2020 World Digital Competitiveness Ranking which measures the capacity and readiness of economies to adopt and explore digital technologies for economic and social transformation ranked countries in the global north and Asia in the top 10 which correlates with the high DE research activities in that territory. 


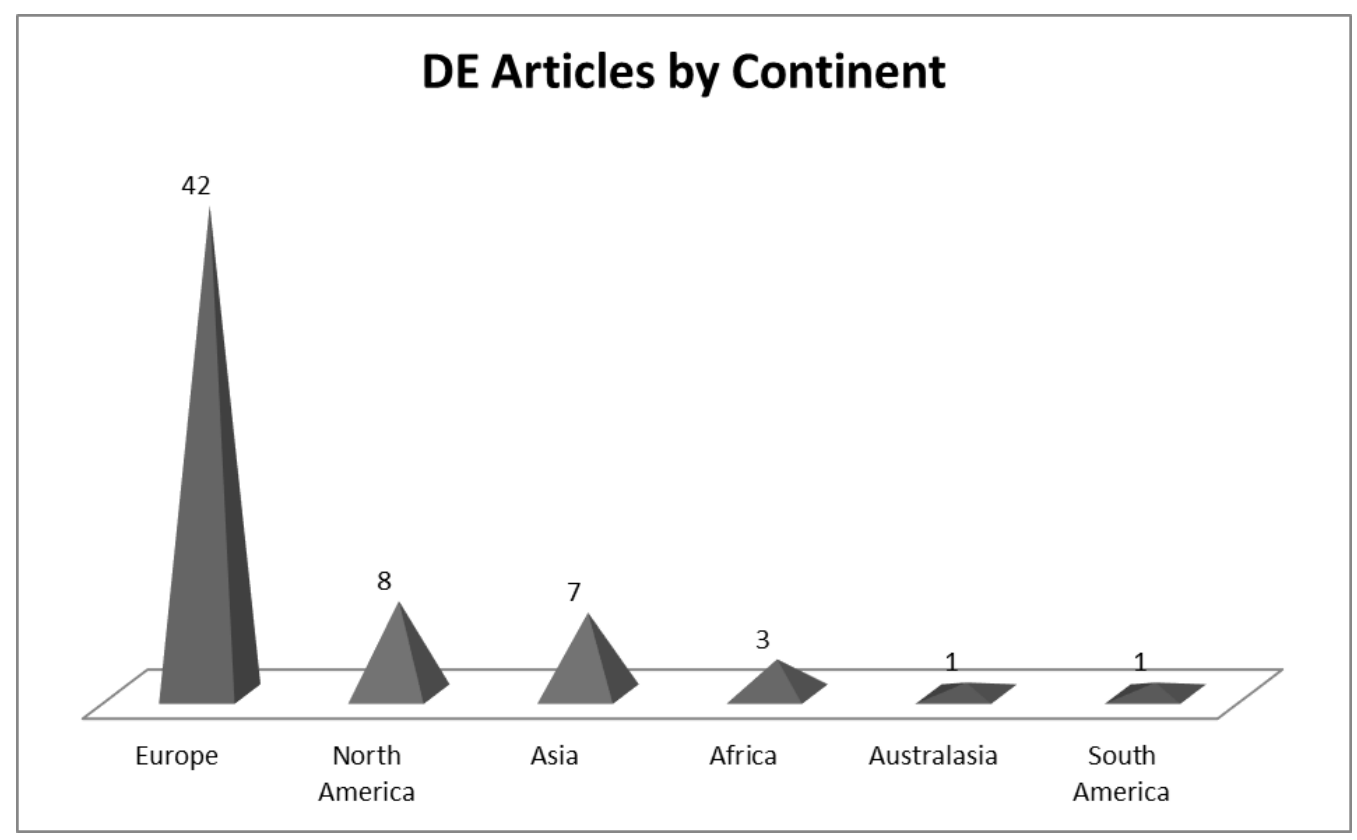

Figure 3: SL articles by continent

Digital Entrepreneurship researchers thus have a role to play in these three continents by conducting studies that will provide empirical evidences of the gains of Digital Entrepreneurship. Their research studies will help to spur an increase in the competitiveness of both the local and national economies in the three continents. Transformation of existing economies into digital economies heralds many opportunities for the accelerated growth of the small and medium-sized enterprises which are the drivers of local and national economies.

\section{Article type}

Figure 4 presents a categorization of the $45 \mathrm{DE}$ articles reviewed based on whether they were empirical or conceptual in nature. It can be observed that equal numbers of the articles reviewed were empirical (22) and conceptual (22) in type while only one was mixed mode.

Empirical and conceptual researches are both important to validate or disprove existing DE theories or models. Figure 4 shows that DE researchers of the last decade have purposefully devoted energy on both forms of research. 


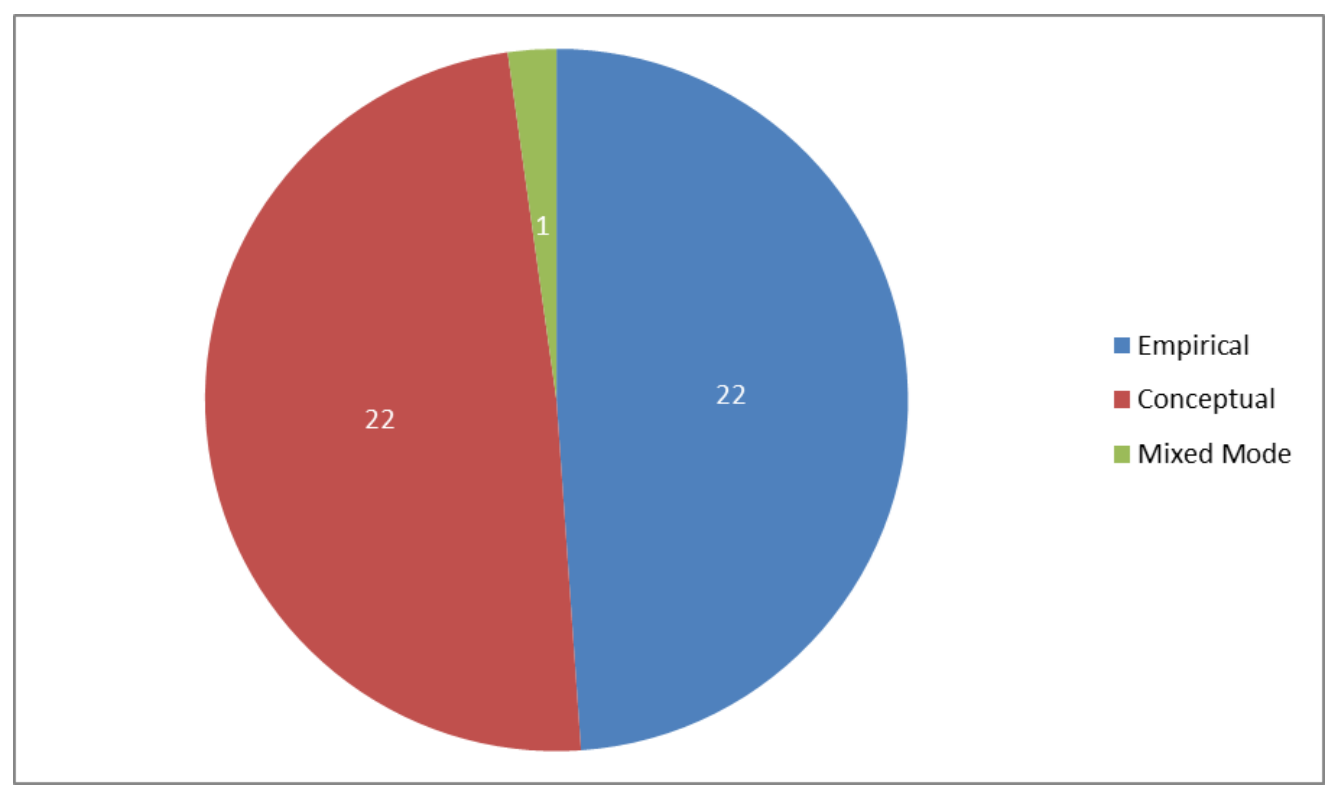

Figure 4: DE Article Types

Conceptual research forms the building blocks of DE research and will establish the research agenda for the next decade of DE research. As the concept of DE matures, future DE researchers may begin to shift to empirical DE research to try to validate the concept of Digital Entrepreneurship.

\section{Data collection methods}

Figure 5 presents the nine different data collection methods utilized by the 23 empirical and mixed mode DE articles examined for this study. It can be seen that about $74 \%$ of the articles (17 out of 23 ) utilized interviews to collect data; this was by far the most utilized method (e.g., Dong, 2019; McAdam et al., 2019; Ngoasong, 2017). Observation was the next most common data collection method used by 6 out of the 23 studies (e.g., Toniolo et al., 2020; Leung, 2019; Arfi, 2019). Five studies utilized secondary data (e.g., Secundo, 2020; David-West, 2018; Li et al., 2017; Toniolo et al., 2020); in joint position with surveys (5 out of 23) (e.g., Yin et al., 2019; Bouncken et al., 2020; Balocco et al., 2019). One study (Obschonka et al., 2017) collected data from questionnaires while another (McAdam et al., 2019) used focus groups. 


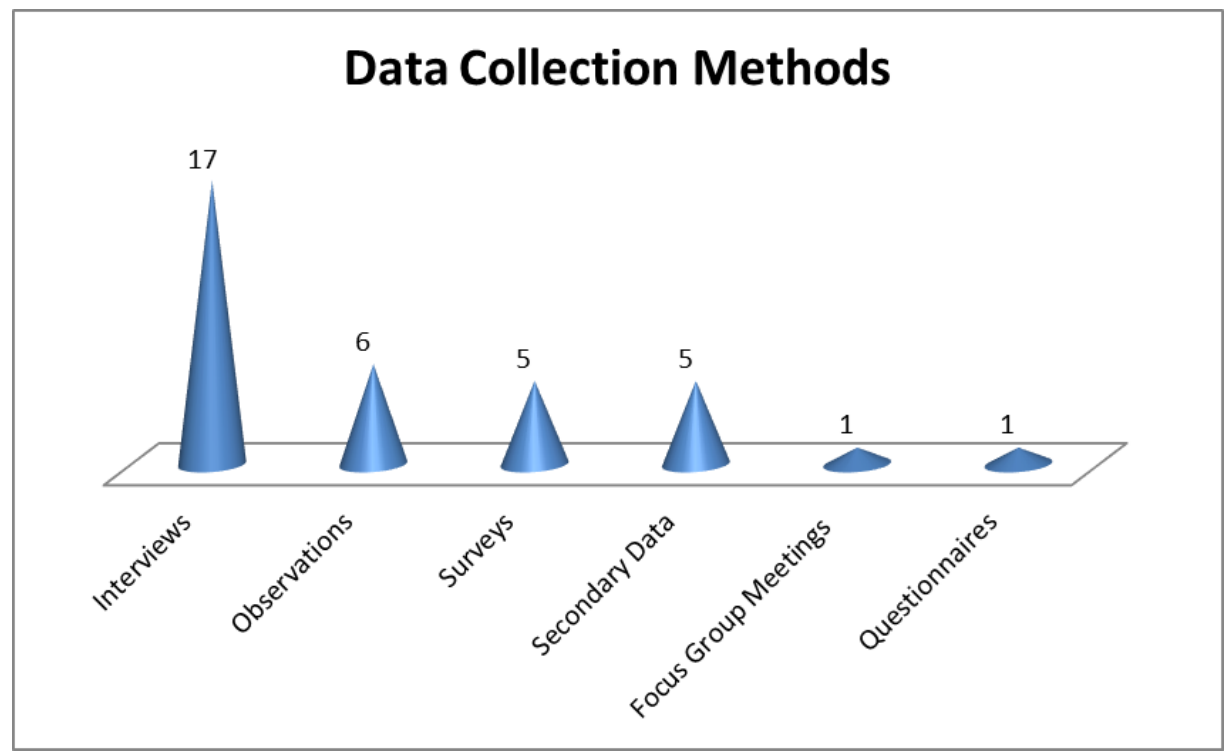

Figure 5: DE Data Collection Methods

Figure 5 revealed an obvious bias towards interviews in the way empirical data was collected by DE studies in the last decade. Although interviews allow researchers to collect data from large samples which make the findings more representative of the target population. However, the almost exclusive use of interviews means that rich and in-depth perspectives of DE that would be obtained via qualitative methods have not been fully explored. It is thus incumbent on future DE researchers to adopt more qualitative data collection methods to provide different insights into the DE phenomenon.

\section{SL Themes}

An analysis of the $45 \mathrm{DE}$ articles reviewed for this study revealed that they explored eight distinct themes which are presented in Figure 6.

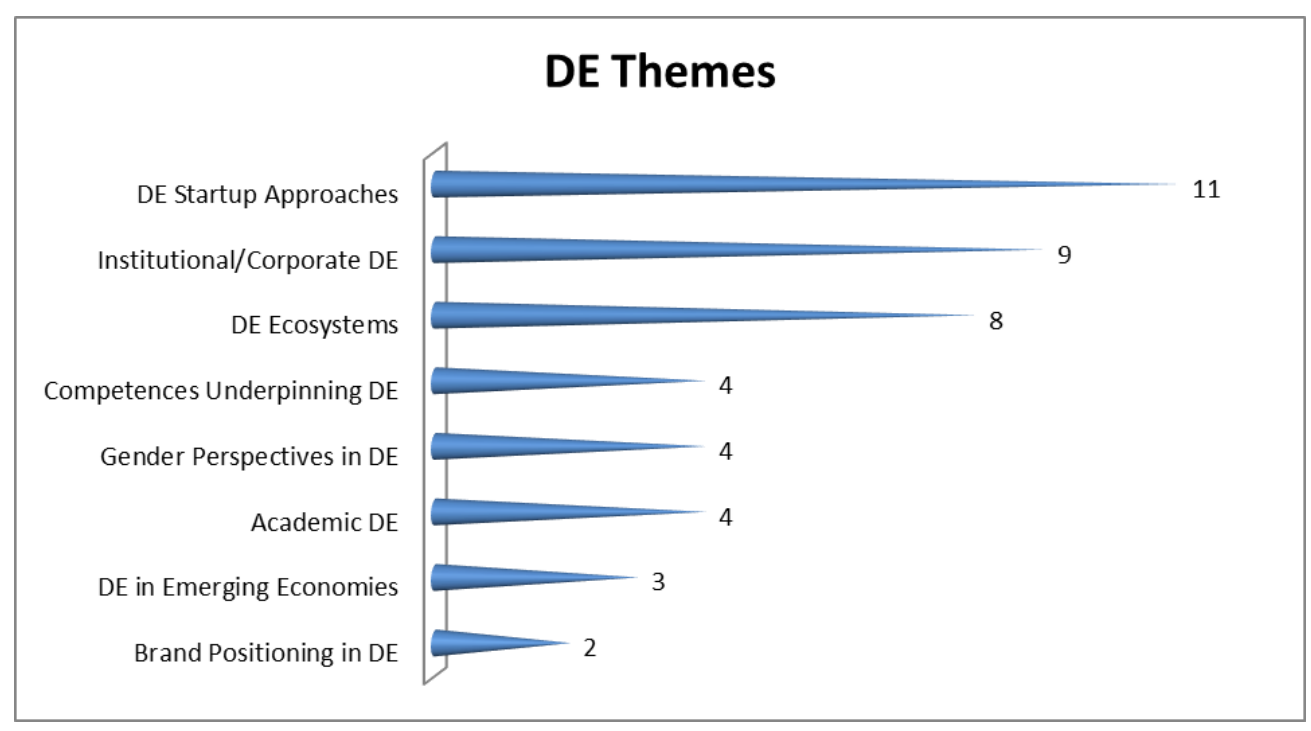

Figure 6: DE Themes 
It can be observed that many of the DE articles examined (11 from 45) explored Digital Entrepreneurship startup approaches. The startup approaches X-rayed included lean and agile methods referred to as the Lean Startup Approaches (LSA) (Ghezia A., 2018 and Balocco et al., 2019); Crowdfunding platforms and "how angel groups and Venture Capital (VC) funds affect growth of digital new ventures in their startup and scaleup phases" (Cavallo et al., 2019 and Finkle, 2019); Entrepreneurial startups and innovation (Hsieh, 2019 and Block et al., 2020); "Innovative business models for the sharing economy" (Richter et al., 2017) the network perspective to successful startups on digital platforms (Srinivasan, 2017).

The next most common theme explored was Institutional and Corporate Digital Entrepreneurship with 9 out of the $45 \mathrm{DE}$ articles pursuing this task. Characteristics identified included the role of institutional entrepreneurship in building DE ecosystems (Hu et al., 2016); "Digital Entrepreneurship and field conditions for institutional change" (Geissinger et al., 2018); Implications for "Digital Entrepreneurship in the regulatory environment" (Dong, 2019); institutional patterns in co-working spaces (Bouncken et al., 2020); innovation and institutional entrepreneurship (Tumbas et al., 2018); and, Challenges and opportunities facing institutional entrepreneurship (de los Reyes, 2019). Joshi et al., (2019) pondered the "spread of the Internet technology as a surrogate for growth of the digital era and examined its impact on organisations."

The third most explored theme ( 8 out of 45 articles) was trying to understand to what extent the DE Ecosystems had diffused across economies, and to investigate whether the meaning of DE remained consistent across the different economies. Li et al., (2017) opined that "studies on Digital Entrepreneurship Ecosystems (DEEs) are limited and the concept is largely undertheorized."

The next set of theme in the studies investigated the Digital Competences Underpinning DE. Ngoasong (2017) critically explored "how context as an antecedent to entrepreneurial digital competencies (EDCs) influences Digital Entrepreneurship in a resource-scarce environment." According to Scuotto (2013) "the ability to efficiently use the latest technology are also relevant in developing entrepreneurship attitude."

Four DE studies investigated whether the saying "what a man can do, a woman can do better" holds true in the case of DE by exploring the gender perspective in DE. MartinezDy et al., (2018) interrogated the notion of Digital Entrepreneurship as an emancipatory phenomenon for women. Ughetto et al., (2019) outlined contributions that intended to enlarge and thicken the comprehension of "whether and how women entrepreneurs leverage new digital technologies in the creation and conduct of new ventures in order to overcome the hurdles they face and concluded with a promising new line of research to the understanding of whether and to what extent new digital technologies provide an opportunity space in the creation and conduct of new ventures for women." McAdam (2020) described Digital Entrepreneurship as a "great leveller in terms of equalizing the entrepreneurial playing field for women."

Four articles making up the sixth theme focused on Academic DE. Rippa, P., Technological Forecasting \& Social Change (2018), offered an "interpretative framework for Digital Academic Entrepreneurship" composed of four components:

- Why - The rationale for the adoption of digital technologies for academic entrepreneurship;

- What - The emerging forms of digital academic entrepreneurship;

- Who - The stakeholders involved through the digital technologies to achieve the academic entrepreneurship goal: and,

- How - The processes of academic entrepreneurship supported by digital technologies. 
Secundo et al., (2020) highlighted the emergence of four major research streams:

- $\quad$ Digital Technologies for Entrepreneurship Education;

- The "maker space movement" for Academic Entrepreneurship;

- Digital technologies for discovering entrepreneurial opportunities; and,

- Creating entrepreneurial competences in the Digital "University-based" Entrepreneurial ecosystems.

In the context of DE in emerging economies, three articles explored the theme from different perspectives. Bowen (2019) investigated the "impact of digital connectivity challenges on rural businesses."

Brand Positioning in DE, the eighth and final theme, contributed two articles to the review. Bahcecik et al., (2019) considered Brand Positioning as central to success in DE.

Table 4: Summary of findings of review of $45 \mathrm{DE}$ articles

\begin{tabular}{|c|c|c|c|}
\hline $\mathbf{S} / \mathbf{N}$ & Heading & Key Findings & Implications \\
\hline 1 & $\begin{array}{l}\text { Time distribution } \\
(2012-2021)\end{array}$ & $\begin{array}{l}\text { - DE articles were published every } \\
\text { year from } 2013 \text { to } 2021 \text { except } \\
2015 \text {. } \\
-2019 \text { and } 2020 \text { were the most } \\
\text { productive years with } 17 \text { and } 10 \\
\text { articles published respectively. }\end{array}$ & $\begin{array}{l}\text { - Interest in DE has in- } \\
\text { creased over the last dec- } \\
\text { ade. }\end{array}$ \\
\hline 2 & $\begin{array}{l}\text { Geographic distribu- } \\
\text { tion }\end{array}$ & $\begin{array}{l}-23 \text { countries had at least one DE } \\
\text { article. } \\
\text { - Italy had the largest number of } \\
\text { SL articles (10) among contributing } \\
\text { countries. } \\
\text { - Europe had the largest number of } \\
\text { DE articles (42) among contrib- } \\
\text { uting continents, while South } \\
\text { America and Australasia had the } \\
\text { least with one apiece. }\end{array}$ & $\begin{array}{l}\text { - There is need for more } \\
\text { DE research in Africa, } \\
\text { South America and Austral- } \\
\text { asia as they were the least } \\
\text { represented by articles re- } \\
\text { viewed. }\end{array}$ \\
\hline 3. & Article type & $\begin{array}{l}\text { - Equal numbers of the articles } \\
\text { reviewed were empirical (22) and } \\
\text { conceptual (22) in type while only } \\
\text { one was mixed mode. }\end{array}$ & $\begin{array}{l}\text { - There is a need for more } \\
\text { conceptual DE research to } \\
\text { form the research agenda } \\
\text { for the next decade of DE } \\
\text { scholarship. }\end{array}$ \\
\hline 4. & $\begin{array}{l}\text { Data collection } \\
\text { methods }\end{array}$ & $\begin{array}{l}\text { - Eight different data collection } \\
\text { methods were identified. } \\
\text { - Interview was the most common } \\
\text { method used (17). }\end{array}$ & $\begin{array}{l}\text { - Future DE researchers to } \\
\text { adopt more qualitative data } \\
\text { collection methods to pro- } \\
\text { vide different insights into } \\
\text { the DE phenomenon. }\end{array}$ \\
\hline 5. & DE Themes & $\begin{array}{l}\text { - Eight distinct DE themes identi- } \\
\text { fied. } \\
- \text { DE Startup was the dominant } \\
\text { theme ( } 11 \text { out of } 45) \text {. }\end{array}$ & $\begin{array}{l}\text { - DE is maturing as a con- } \\
\text { cept and is set to dominate } \\
\text { the world of entrepreneur- } \\
\text { ship in the years ahead. }\end{array}$ \\
\hline
\end{tabular}

Source: Author's review (2021) 


\section{CONCLUSION}

Digital Entrepreneurship comprises everything that is new and innovative about entrepreneurship in a digital world. This incorporates novel methods of sourcing customers for businesses; fresh methods of delivering products and services; modern ways of generating value while minimising costs; finding new possibilities to cooperate with other partners; sniffing out new opportunities and competitive advantages.

As Digital Entrepreneurship evolves, businesses will transform with time. Not too far into the future, enterprises will be born digital. Then Digital Entrepreneurship as a topic will become conventional. For now, there is a need to prepare entrepreneurs for the digital world and to give people an altogether new pathway to entrepreneurship. It was against this backdrop that this paper conducted a sys-tematic review of Digital Entrepreneurship scholarship over the last decade (2012-2021). Forty five DE articles were reviewed across five headings: time distribution, geographic distribution, article type, data collection methods and DE themes, with key findings and their implications for knowledge and practice analysed for each heading.

Perhaps the most important finding of this review was that significant empirical evidence exists regarding the efficacy of Digital Entrepreneurship. The major implication of this finding for leaders today, whether public or private, is that servant leadership is indeed a philosophy worth learning about and adopting to ensure that organizations and countries alike can achieve their stated objectives.

This review had certain limitations which future researchers can address. First, it only relied on journal articles published by five of the most popular academic publishers: Elsevier Emerald, Sage, Springer and Wiley. Although this was done to ensure the quality of articles reviewed, it means that other valuable DE articles not published by these publishers have been excluded. Future researchers can widen the article selection criteria to increase the robustness of the review. A second limitation is the fact that only articles with the phrase "Digital Entrepreneurship" in their titles were included for selection; many DE articles might not have included that phrase in their titles and thus were not captured by this review.

What makes Digital Entrepreneurship topical is its promise of a better world once it gains global traction.

\section{REFERENCES}

Arfi, W. B., \& Hikkerova, L. (2019). Corporate entrepreneurship, product innovation, and knowledge conversion: the role of digital platforms. Small Business Economics, 1-14.

Bahcecik, Y. S., Akay, S. S., \& Akdemir, A. (2019). A Review of Digital Brand Positioning Strategies of Internet Entrepreneurship in the Context of Virtual Organizations: Facebook, Instagram and Youtube Samples. Procedia Computer Science, $158,513-522$.

Balocco, R., Cavallo, A., Ghezzi, A., Barbegal-Mirabent, J. (2019). Lean Business Models Change Process in Digital Entrepreneurship. Business Process Management Journal, 1-24.

Basly, S., \& Hammouda, A. (2020). Family businesses and digital entrepreneurship adoption: A conceptual model. The Journal of Entrepreneurship, 29(2), 326364. 
Bouncken, R., Ratzmann, M., Barwinski, R., \& Kraus, S. (2020). Coworking spaces: Empowerment for entrepreneurship and innovation in the digital and sharing economy. Journal of Business Research, 114, 102-110.

Bowen, R., \& Morris, W. (2019). The digital divide: Implications for agribusiness and entrepreneurship. Lessons from Wales. Journal of Rural Studies, 72, 75-84.

Cavallo, A., Ghezzi, A., Dell'Era, C., \& Pellizzoni, E. (2019). Fostering digital entrepreneurship from startup to scaleup: The role of venture capital funds and angel groups. Technological Forecasting and Social Change, 145, 24-35.

David-West, O., \& Nwagwu, I. (2018). SDGs and Digital Financial Services (DFS) Entrepreneurship: Challenges and Opportunities in Africa's Largest Economy. Contemporary Issues in Entrepreneurship Research, 103-117. doi:10.1108/ s2040-724620180000008011

de Los Reyes Jr, G. (2019). Institutional entrepreneurship for digital public health promotion: Challenges and opportunities. Health Education \& Behavior, 46 (2_suppl), 30S-36S.

Dong, J. Q. (2019). Moving a mountain with a teaspoon: Toward a theory of digital entrepreneurship in the regulatory environment. Technological Forecasting and Social Change, 146, 923-930.

Fang, Y., Henfridsson, O., \& Jarvenpaa, S. L. (2018). Editorial on generating business and social value from digital entrepreneurship and innovation. Journal of Strategic Information Systems, 27(4), 275-277.

Finkle, T. A., \& Olsen, T. (2019). Entrepreneurship in the digital era: creating your own online business. Entrepreneurship Education and Pedagogy, 2(2), 133150.

Galindo-Martín, M. Á., Castaño-Martínez, M. S., \& Méndez-Picazo, M. T. (2019). Digital transformation, digital dividends and entrepreneurship: A quantitative analysis. Journal of Business Research, 101, 522-527.

Geissinger, A., Laurell, C., Sandström, C., Eriksson, K., \& Nykvist, R. (2019). Digital entrepreneurship and field conditions for institutional change-Investigating the enabling role of cities. Technological Forecasting and Social Change, 146, 877886.

Ghezzi, A., \& Cavallo, A. (2020). Agile business model innovation in digital entrepreneurship: Lean startup approaches. Journal of business research, 110, 519-537.

Hu, H., Huang, T., Zeng, Q., \& Zhang, S. (2016). The role of institutional entrepreneurship in building digital ecosystem: A case study of Red Collar Group (RCG). International Journal of Information Management, 36(3), 496-499.

Hsieh, Y. J., \& Wu, Y. J. (2019). Entrepreneurship through the platform strategy in the digital era: Insights and research opportunities. Computers in Human Behavior, 95, 315-323.

Jafari-Sadeghi, V., Garcia-Perez, A., Candelo, E., \& Couturier, J. (2021). Exploring the impact of digital transformation on technology entrepreneurship and technological market expansion: The role of technology readiness, exploration and exploitation. Journal of Business Research, 124, 100-111.

Joshi, M. P., Kathuria, R., \& Das, S. (2019). Corporate entrepreneurship in the digital era: the cascading effect through operations. The Journal of Entrepreneurship, 28(1), 4-34. 
Ladeira, M. J., Ferreira, F. A., Ferreira, J. J., Fang, W., Falcão, P. F., \& Rosa, Á. A. (2019). Exploring the determinants of digital entrepreneurship using fuzzy cognitive maps. International Entrepreneurship and Management Journal, 15(4), 1077-1101.

Leung, W. F., \& Cossu, A. (2019). Digital entrepreneurship in Taiwan and Thailand: Embracing precarity as a personal response to political and economic change. International Journal of Cultural Studies, 22(2), 264-280.

Li, W., Du, W., \& Yin, J. (2017). Digital entrepreneurship ecosystem as a new form of organizing: the case of Zhongguancun. Frontiers of Business Research in China, 11(1), 1-21.

Martinez Dy, A., Martin, L., \& Marlow, S. (2018). Emancipation through digital entrepreneurship? A critical realist analysis. Organization, 25(5), 585-608.

McAdam, M., Crowley, C., \& Harrison, R. T. (2019). "To boldly go where no [man] has gone before"-Institutional voids and the development of women's digital entrepreneurship. Technological Forecasting and Social Change, 146, 912-922.

Nambisan, S. (2017). Digital entrepreneurship: Toward a digital technology perspective of entrepreneurship. Entrepreneurship theory and practice, 41(6), 10291055 .

Ngoasong, Michael Zisuh (2018). Digital entrepreneurship in a resource-scarce context: A focus on entrepreneurial digital competencies. Journal of Small Business and Enterprise Development, 25(3) pp. 483-500

Obschonka, M., Fisch, C., \& Boyd, R. (2017). Using digital footprints in entrepreneurship research: A Twitter-based personality analysis of superstar entrepreneurs and managers. Journal of Business Venturing Insights, 8, 13-23.

Oppong, G. Y. S., Singh, S., \& Kujur, F. (2020). Potential of digital technologies in academic entrepreneurship - a study. International Journal of Entrepreneurial Behavior \& Research, ahead-of-print(ahead-of-print). doi:10.1108/ijebr-062019-0401

Paek, B., \& Lee, H. (2018). Strategic entrepreneurship and competitive advantage of established firms: evidence from the digital TV industry. International Entrepreneurship and Management Journal, 14(4), 883-925.

Park, H., Kim, S., Jeong, Y., \& Minshall, T. (2021). Customer entrepreneurship on digital platforms: Challenges and solutions for platform business models. Creativity and Innovation Management, 30(1), 96-115.

Richter, C., Kraus, S., Brem, A., Durst, S., \& Giselbrecht, C. (2017). Digital entrepreneurship: Innovative business models for the sharing economy. Creativity and Innovation Management, 26(3), 300-310.

Quinones, G., Nicholson, B., \& Heeks, R. (2015). A literature review of Eentrepreneurship in emerging economies: Positioning research on Latin American digital startups. Entrepreneurship in BRICS, 179-208.

Rippa, P., \& Secundo, G. (2019). Digital academic entrepreneurship: The potential of digital technologies on academic entrepreneurship. Technological Forecasting and Social Change, 146, 900-911.

Sahut, J. M., Iandoli, L., \& Teulon, F. (2019). The age of digital entrepreneurship. Small Business Economics, 1-11.

Scuotto, V., \& Morellato, M. (2013). Entrepreneurial knowledge and digital competence: Keys for a success of student entrepreneurship. Journal of the Knowledge Economy, 4(3), 293-303. 
Secundo, G., Rippa, P., \& Cerchione, R. (2020). Digital Academic Entrepreneurship: A structured literature review and avenue for a research agenda. Technological Forecasting and Social Change, 157, 120118.

Srinivasan, A., \& Venkatraman, N. (2018). Entrepreneurship in digital platforms: A network-centric view. Strategic Entrepreneurship Journal, 12(1), 54-71.

Steel, G. (2021). Going global-going digital. Diaspora networks and female online entrepreneurship in Khartoum, Sudan. Geoforum, 120, 22-29.

Steininger, D. M. (2019). Linking information systems and entrepreneurship: A review and agenda for IT-associated and digital entrepreneurship research. Information Systems Journal, 29(2), 363-407.

Toniolo, K., Masiero, E., Massaro, M., \& Bagnoli, C. (2020). A grounded theory study for digital academic entrepreneurship. International Journal of Entrepreneurial Behavior \& Research, ahead-of-print(ahead-of-print). doi:10.1108/ijebr-062019-0402

Tumbas, S., Berente, N., \& Brocke, J. V. (2018). Digital innovation and institutional entrepreneurship: Chief Digital Officer perspectives of their emerging role. Journal of Information Technology, 33(3), 188-202.

Ughetto, E., Rossi, M., Audretsch, D., \& Lehmann, E. E. (2019). Female entrepreneurship in the digital era. Small Business Economics, 1-8.

Wentrup, R., Nakamura, H. R., \& Ström, P. (2020). Closing the Digital Entrepreneurship Gap the Case of Returnee Entrepreneurs in Morocco. Journal of Entrepreneurship and Innovation in Emerging Economies, 6(1), 140-162.

Wu, Y. J., Lin, S. J., \& Hsieh, Y. J. (2019). Entrepreneurship and innovation in the digital era. Computers in Human Behavior, 95, 233-237.

Yin, Z., Gong, X., Guo, P., \& Wu, T. (2019). What drives entrepreneurship in digital economy? Evidence from China. Economic Modelling, 82, 66-73.

Ziyae, B., Sajadi, S. M., \& Mobaraki, M. H. (2014). The deployment and internationalization speed of e-business in the digital entrepreneurship era. Journal of Global Entrepreneurship Research, 4(1), 1-11. 